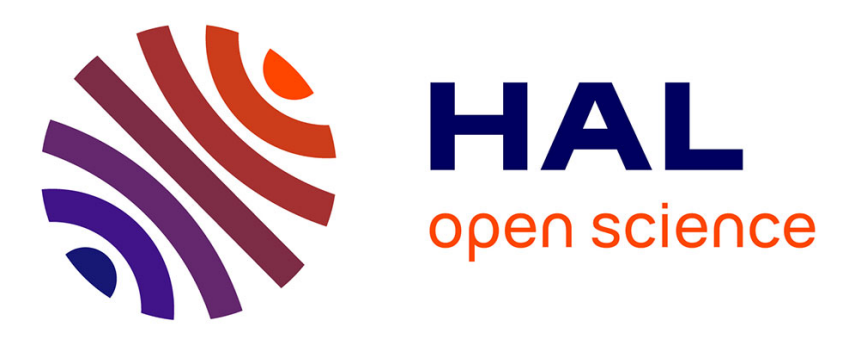

\title{
The Role of Standardisation in the Shaping of a Vision for Nanotechnology
}

\author{
Aurélie Delemarle, Harald Throne-Holst
}

\section{To cite this version:}

Aurélie Delemarle, Harald Throne-Holst. The Role of Standardisation in the Shaping of a Vision for Nanotechnology. International Journal of Innovation and Technology Management, 2012, 10 (2), 20 p. $10.1142 / \mathrm{S} 0219877013400051$. hal-00844372

\section{HAL Id: hal-00844372 \\ https://hal-enpc.archives-ouvertes.fr/hal-00844372}

Submitted on 15 Jul 2013

HAL is a multi-disciplinary open access archive for the deposit and dissemination of scientific research documents, whether they are published or not. The documents may come from teaching and research institutions in France or abroad, or from public or private research centers.
L'archive ouverte pluridisciplinaire HAL, est destinée au dépôt et à la diffusion de documents scientifiques de niveau recherche, publiés ou non, émanant des établissements d'enseignement et de recherche français ou étrangers, des laboratoires publics ou privés. 


\title{
"The Role of Standardisation in the Shaping of a Vision for Nanotechnology"
}

\author{
Aurélie Delemarle ${ }^{1}$ \\ Université Paris Est-LATTS -ESIEE Management \\ a.delemarle@esiee.fr \\ Harald Throne-Holst \\ National Institute for Consumer Research (SIFO) \\ harald.throne-holst@sifo.no
}

\begin{abstract}
Nanotechnologies are known as emerging technologies. In contrast to this there are already products on the market that claim to incorporate these technologies. This has contributed to the growing interest in the regulation of this field. In this paper, we first introduce the question of regulation in nanotechnologies, then describe the standardisation process and ISO more specifically. This introduction is followed by the main point of the article: we show the specific role that the ISO TC 229 plays in the beginning of the shaping of a collective vision for nanotechnologies. We point to the organisation and re-organisation of TC 229 that allows actors to build a collective representation of the evolving field and build legitimacy at the global level. We argue that beyond the production of standards, this aspect is central in an emerging field that will impact regulators as they design new rules.
\end{abstract}

\section{Introduction}

\section{Regulation in nanotechnologies}

\section{The willingness to regulate nanotechnologies}

Nanotechnologies raise big regulatory questions about how governments should govern this set of technologies in a sensible way: big because the influence of nanotechnology will come in many or most field and sectors (Ozin and Arsenault, 2005; Larédo et al., 2010). Further the questions will be big as in order to have an appropriate response to the challenges, input from various disciplines will be needed. And finally, although the nanotechnologies are something that all nations will need to address in their national context, international cooperation will probably be required to achieve a thorough response (Ludlow et al., 2007).

But despite the size of the regulatory challenges, governments have taken up the challenge and started to work at different levels: regionally, nationally and internationally.

\section{Different ways to regulate nanotechnologies}

\footnotetext{
${ }^{1}$ The authors acknowledge the support of ANR (NanoBench $n^{\circ}$ ANR-07-. NANO-026 and NanoExpectations $\mathrm{n}^{\circ}$ ANR-09-P36-03 projects). They also wish to thank Ellen Marie Forsberg for her comments as well as members of the AFNOR committee and ISO TC229.
} 
Regulation of emerging technologies like nanotechnology can take on different forms. It does not only imply to regulate products that should be available on the shelves, but it could also include forbidding or restricting further research in different fields. Two examples here are the Norwegian moratorium on the cloning of animals or humans after the apperance of the cloned sheep Dolly (Stortinget, 1997), or perhaps best known President Bush's ban on federal funding for research on human embryonic stem-cell lines (Wadman, 2009).

At the other end of the regulatory spectrum, there could be no specific regulation at all, like for the Internet (with a few limited exceptions though; like pornography and domain names) (Hodge et al., 2007). In between these two extremes we can find varying degrees of voluntary and mandatory measures, including traditional hard law approaches or self-regulation, implying forms of soft law (ibid.; Abbott and Snildal, 2000).

\section{When should regulations be imposed?}

Regarding the possible regulation of emerging technologies, we soon end up in a question of timing: When should regulatory measures be introduced? If regulation occurs too early, the risk is to stop technological developments that could have resulted in both benign products and (national) economic benefits. If it happens too late .. damage could already have been done, and large investments could have been made. Relevant in this context are the frequent calls for precaution. If regulation happens early, precaution would probably be part of the reasoning. Regulators would then have to ponder on the question of what kinds of (early) warnings could justify such measures.

\section{The Precautionary Principle}

However, an implementation of the precautionary principle could be problematic, and this has been a matter of dispute between Europe and the US. Europeadopted the Precautionary Principle in several agreements and treaties, e.g. in the Maastricht treaty, but this is not favoured by the US. The two jurisdictions still disagree on the content and extent of an implementation of the precautionary principle.

But even if we would agree on the need to take precautionary action, the format it would take is not clear. Can you be precautionary even when developments have passed certain thresholds, - can you so to speak be precautionary in parallel with developments? This might seem as a contradiction, but it is at least part of what European regulators are doing, evident in their promotion of the notion of "continual vigilance" (Throne-Holst et al., 2009).

Further, an important dimension in the discussions on regulations is the question of legitimacy. This concerns both the question of who should be precautionary (Throne-Holst and Stø, 2008) and what happens when regulatory zones move beyond a state to cover regions or worldwide jurisdictions (Brownsword, 2008).

\section{Standardisation is a part of regulation}

Standards are used actively in regulation today, and their benefits are actively promoted by ISO. ISO/IEC (2007)"... explains how ISO and IEC standards can be used by governments to support good regulatory practice". Regulators can decide whether the use of the ISO or IEC 
standard is mandatory (so it provides the only solution) or voluntary (providing one solution out of many).

The question that we want to raise is the role of standardisation in the regulation of nanotechnology. We argue that for an emerging field, the issue of standardisation does not only rely on the production of normative documents that will be used by regulators. The notion of vision shaping is also central. To develop this point, we use the framework of field configuring events in the analysis of the case study on nanotechnology. We first go back to the role of standardisation and show to what extend it is relevant in an emerging field context. We then present the methods and case study that we discuss in the next section before concluding.

\section{Standardisation}

The historical roots of standardisation goes back hundreds years ago, in the fields of weights and measures, coinage and product standards (for an interesting recollection of this often colourful story, we recommend the article of Hendrik Spruyt (2001)). International standardisation today concerns materials, products, processes or services. So far, standardisation has not been considered relevant in fields that have no (final) product.

We use here the definition of standard ${ }^{2}$ as a document, established by consensus and approved by a recognized body, that provides, for common and repeated use, rules, guidelines or characteristics for activities or their results, aimed at the achievement of the optimum degree of order in a given context.

As standards support the interoperability of products, they thus facilitate trade between countries (ISO, 2008). Standards contribute to make market-transactions more efficient way. They also allow a development of a separate sector of suppliers of spare parts as well as repair

2 The literature actually distinguishes different kinds of standards. First is the distinction between de iure and de-facto standards: de iure standards are those established through the institutions involved in standard-setting, whereas de-facto standards are those selected by the market between competing technologies (Keil, 2002). These standards are developed outside the traditional standardisation framework, and are often thought to appeal to narrower markets (ANSI, 2007), than the de iure standards. They are even referred to as nonconsensus standards, as they well be a result of one firm forcing its competitors to adopt its technological solution by achieving control over the underlying technology. Microsoft's operating system is the classic example of such a standard (Tassey, 2000). The distinction separating de iure and de-facto is parallel to that between market-based and committee-based standards (Keil, 2002; Spruyt, 2001).

The distinction between retrospective and anticipatory standards (Rashba et al., 2004) is here very useful, because it shows, that despite the lack of products on the market, standardisation can be relevant. Retrospective standards have historically been dominant. Standards where chosen from a pool of existing candidate solutions to well-known problems and needs. Anticipatory standards on the other hand start by defining a problem; or rather proscribe a desired performance. As such they are forward-looking, and they precede products and procedures. Successful examples include Wi-Fi ("Wireless Fidelity") (ibid.) and the Bluetooth initiative (Keil, 2002). 
and maintenance (Tassey, 2000). They might make the development, production and supply of products and services more efficient, safer and cleaner.With standards, manufacturers can achieve economies of scale.

Standardisation may take place on different levels:

- at the international level through ISO /IEC,

- at the regional level, like The European Committee for Standardization (CEN)

- at the national level, like American National Standards Institute (ANSI)

For the ISO system alone more than 3000 technical groups develop standards, involving approximately 50000 experts. This has contributed to a portfolio of more than 17000 ISOstandards as of December 2008 (ISO, 2009).

The Vienna agreement regulates the relation between ISO and CEN. This agreement seeks to prevent duplication and increase the transparency between the two. It is an agreement on a technical cooperation.

The relation between other standard organisations is mainly through the World Trade Organization (WTO) Agreement on Technical Barriers to Trade ("TBT") where signatories commit themselves to internationally accepted principles of the standardisation process, to promote and use international standards of the type developed by ISO (ANSI, 2007; ISO, 2006).

There are three main steps in the development of a standard in the ISO system (ISO 2010):

1) Recognising the need for an international standard

2) Working and negotiating the detailed specifications of the standard

3) Formal approval of the draft standard

1) First a need for a standard is expressed, usually from the manufacturing side: this need is communicated to a National member body of the ISO. This national body then proposes a new work item to ISO Central Secretariat. This proposal includes a designated list of elements, among them a "Scope" as well as "Purpose and justification". If ISO can identify sufficient interest in the new field' it establishes a new technical committee (TC). The interest of members is evaluated based on two criteria:

- a majority of $2 / 3$ of the national bodies voting in favour of the proposal, and

- at least 5 national bodies expressing their willingness to work on the project actively.

2) When the committee has reached an agreement on technical aspects the standards should cover, the negotiation of more the detailed specifications within the standard is negotiated. This is the consensus-building phase.

3) In the final phase the formal approval of the resulting draft International Standard takes place. To be approved, at least $2 / 3$ of the ISO members that have participated actively in the standards development process have to vote in favour, and $75 \%$ of all voting members . After this, the agreed text is published as an ISO International Standard.

In the context of TC229 Nanotechnology, three types of deliverables from the ISO work are relevant (Table 1): 
Table 1: ISO deliverables (ISO, 2010)

\begin{tabular}{|l|l|l|}
\hline Acronym & Full name & Definition \\
\hline ISO/TS & Technical Specification & $\begin{array}{l}\text { A normative document } \\
\text { representing th technical } \\
\text { consensus within an ISO } \\
\text { lommittee }\end{array}$ \\
\hline ISO & Technical Report & $\begin{array}{l}\text { An informative document } \\
\text { containing information of a } \\
\text { different kind from that } \\
\text { normally published in a } \\
\text { normative document }\end{array}$ \\
& International Standard & $\begin{array}{l}\text { A normative document, } \\
\text { developed according to } \\
\text { consensus procedures, which } \\
\text { has been approved by the } \\
\text { ISO membership and P- } \\
\text { members of the responsible } \\
\text { committee in accordance } \\
\text { with Part 1 of the ISO/IEC } \\
\text { Directives as a draft } \\
\text { International Standard and/or } \\
\text { as a final draft International } \\
\text { Standard and which has been } \\
\text { published by the ISO Central } \\
\text { Secretariat. }\end{array}$ \\
&
\end{tabular}

\section{Nanotechnologies and standardisation}

There is broad consensus on the benefits of standardisation. But standardisation also has some important shortcomings or some limits that is part of the motivation for this article. One of the challenges is how standardisation work can be expected to function within an area as the nanotechnologies, which are emerging and therefore will go through phases with rapid developments, both new discoveries in the laboratory, but also in range of practical applications in products.

Nanotechnologies are still in the emerging phase, in between science and technology ${ }^{3}$ and developing at a global scale (Delemarle et al;, 2009). It is said that they are in the second out of four stages ${ }^{4}$ of industrial prototyping and commercialisation (Roco and Bainbridge, 2001)

Standardisation is now well under way for the nanotechnologies. The ISO TC 229 was established in June 2005, whereas the CEN/TC 352 was established half a year later, in November 2005 (Hatto, 2009). For topic of mutual interest the two committees the Vienna

\footnotetext{
3 Larédo et al., 2009 show that publications (science) have a rate of growth of 14\% per year between 1998 and 2006, while this rate is 3\% at the scale of the Web of Science. However, patents (technology ) do not show the same dynamics : there is a ratio of 1 to 3 in number between patents and publications; the authors also point to a decrease in patent applications at the end of the period. They conclude that we are still more in an exploration phase than in an exploitation one.

${ }^{4}$ 1. Deveoplemnt of passive nanostructures; 2 . Active nanostructures; 3 Systems of nanostructures; Molecular nanosystems in network
} 
Agreement will be implemented, with an ISO lead (CEN, 2006). Some would say that the establishment of these would be nothing new, as there already are hundreds of products that claim to be nanoproducts at the consumer market (Throne-Holst and Strandbakken, 2009; Throne-Holst and Stø, 2008, Woodrow Wilson Centre, 2010). But these products are not the scope of the standardisation processes. Rather: "Internationally agreed ISO standards on the basic features of nanotechnologies will help to disseminate them and to increase the size of the market for the derived products" (Bryden, 2005)

A committee's first task is to agree on a scope for the work. In the case of the establishment of the technical committee on Nanotechnologies (ISO/TC 229) this work item was proposed by British Standards Institute. The first meeting took place in London in November 2005. 23 countries had assigned themselves as active participants in the TC, and 7 countries had assigned as "Observers". These numbers have since increased to 32 participating countries, and 11 Observers (ISO/IEC 2010b)

The chairman of the committee TC 229 details the role of standardisation as to:

1. To support commercialisation and market development

2. To provide a basis for procurement through technical requirements, and quality and environmental management

3. To support voluntary governance structures and appropriate legislation and regulation

But how can regulation use standards for products that apparently do not yet exist? Standards are one kind of output from a technical committee that may well be used for regulation. In this instance and there is currently a realised need such as the one from the Cosmetics Directive of the European Union (EU) "..., it is necessary to develop a uniform definition for nanomaterials at international level. The Community should endeavour to reach an agreement on a definition in appropriate international fora. Should such an agreement be reached, the definition of nanomaterials in this Regulation should be adapted accordingly" (EU 2009). There could be good reasons for such alignments not least to prevent nanospecific regulations in Europe to otherwise come out of tune with those in other regions (Bowman et al. 2010).

However, there is a second important output for the definition of a regulation for nanotechnology: it is the vision that the TC creates and diffuses in the different arenas with which it is connected. We argue that this shaping is playing a crucial role in the definition of possible regulations.

We build our argument using as a framework the concept of Field configuring events.

\section{A field in an emerging state needs to be organised: FCE theory.}

Field Configuring Event (FCE) theory provides a better understanding of the mechanisms shaping the development of trajectories of technologies, markets, or industry (Lampel and Meyer 2008). FCE encompasses a variety of settings such as tradeshows, professional conferences (Garud 2008), technology contests (Rao 1994). They all aim at impacting technologies, industries, or markets that are in a transition period. They are defined as "settings in which people from diverse organizations and with diverse purposes assemble periodically, or on a one-time basis, to announce new products, develop industry standards, construct social networks, recognize accomplishments, share and interpret information, and transact business" (Lampel et al. 2006). 
In a special issue of Journal of Management Studies, FCEs are defined based on six characteristics:

"(1) They assemble in one location actors from diverse geographies and organizations.

(2) Their duration is limited, running from a few hours to at most few days.

(3) They provide unstructured opportunities for face-to-face social interaction among participants.

(4) They feature and depend heavily on ceremonial and dramaturgical activities.

(5) They are occasions for information exchange and collective sensemaking.

(6) They generate social and reputational resources that can be deployed elsewhere and to other purposes." (Lampel and Meyer 2008)

Institutional theories have taught us that the weight of existing norms and rules hinder the possibility of change (Giddens 1979). Change happens as practices change (Philipps et al., 2001) or as individuals stand to change organisations (Greenwood and Suddaby, 2006; Delemarle, 2007). But in between, we can also point to the role of social collectives. Meyer et al. (2005) show that as a field is emerging, the density and intensity of participants' interactions is critical for its structuring, especially for the cognitive aspects including identity building (Rao, 1994; Garud and Karnoe, 1994) of its members but also for legitimacy building both within the field in emergence and for the field within the society at large (Aldrich and Fiol, 1994).

FCEs are a result of the evolution of the field and at the same time can largely impact on its trajectory. However, no outcomes can be defined in advance. Interactions happening during the meeting shape them. FCE offers an interesting perspective because it stands between a macro perspective (the development of a field) and a micro perspective (the micro processes occurring during the event).

We use this framework and analyse the functioning of FCEs in the field of standardisation to better understand the role of standardisation in the regulation of an emerging field like the nanotechnologies. FCE theory brings the cognitive and social aspects that lack in this relation. We show that standardisation is not only the production of documents that could be used in a regulatory context but also create a vision that can impact the design of regulation.

\section{Methods}

We base our case study on an in depth participation to the ISO TC 229 committee as well as to national participations to the French and Norwegian national mirror committee in which the two authors sit.

One of the authors ${ }^{5}$ participated in the last four international meetings in Bordeaux (May 2008), Shanghai (November 2008), Seattle (June 2009) and Tel-Aviv (October 2009) as a representative of her national delegation. It was a challenge to participate to the ISO work program as a member of a delegation with a specific role and as an observer of the field in formation. On the other hand, being an active part of a committee is the only way to have access to experts' documents. Indeed, it is required to be member of a subcommittee to have

\footnotetext{
${ }^{5}$ The second author also has practical experience of standardisation through active participation of a working group under CEN/TC 52 "Safety of Toys" from 1996 to 2001.
} 
access to the working documents; otherwise, only the draft document is available to the public when it goes to ballot.

In the ISO TC229 experts meet every six months in a different country and never twice in a row on the same continent. These measures are taken to increase the geographical diversity of its members.

ISO Technical Committee 229 meetings are considered as field configuring events in the sense that national delegates meet on a biannual basis for five days and discuss work in progress. However, one should note that these events are not the place for technical work per se. Only a small fraction of the experts working on projects participate to the meetings. Technical work happen in-between meetings mostly by emails and telephone conferences. Biannual meetings aim at strategic decisions and are the place for lobbying (Delemarle, 2009a)

\section{Case study : ISO TC 229 "Nanotechnologies"}

\section{Participating countries}

Taking into account the participants to the committee meetings in Bordeaux (June 2008), Shanghai (November 2008) and Seattle (June 2009), in average 150 delegates participated in the meetings. We take into consideration only these three meetings to illustrate the representation of countries as they took place in three different continents. Knowing that when a meeting is taking place in France, French and neighbouring countries delegates are "over-represented"; when a meeting is taking place in China, Chinese and neighbouring countries delegates are correspondingly "over-represented"; when a meeting is taking place in the USA, American and Canadian delegates are "over represented". Due to this phenomenon is it not possible to evaluate the representation of countries on the basis of a single meeting. The meeting in Tel Aviv is not considered here due to the financial crisis that arose as well as visa issues for travelling to Israel. Figure 1 shows the global attractiveness of these meetings.

Even though participants to the committee's meetings are first of all national delegates working for the global good, we should also consider their institutional origins (Figure 2). We make a distinction between industry (31\% of the delegates), governmental structures (laboratories or national standards bodies $-63 \%$ of the delegates), universities ( $5 \%$ of the delegates) and others (essentially consumers' representatives $-1 \%$ of the delegates).

Figure 1: Citizenships of TC 229 Delegates (presence at all 3 meetings) 


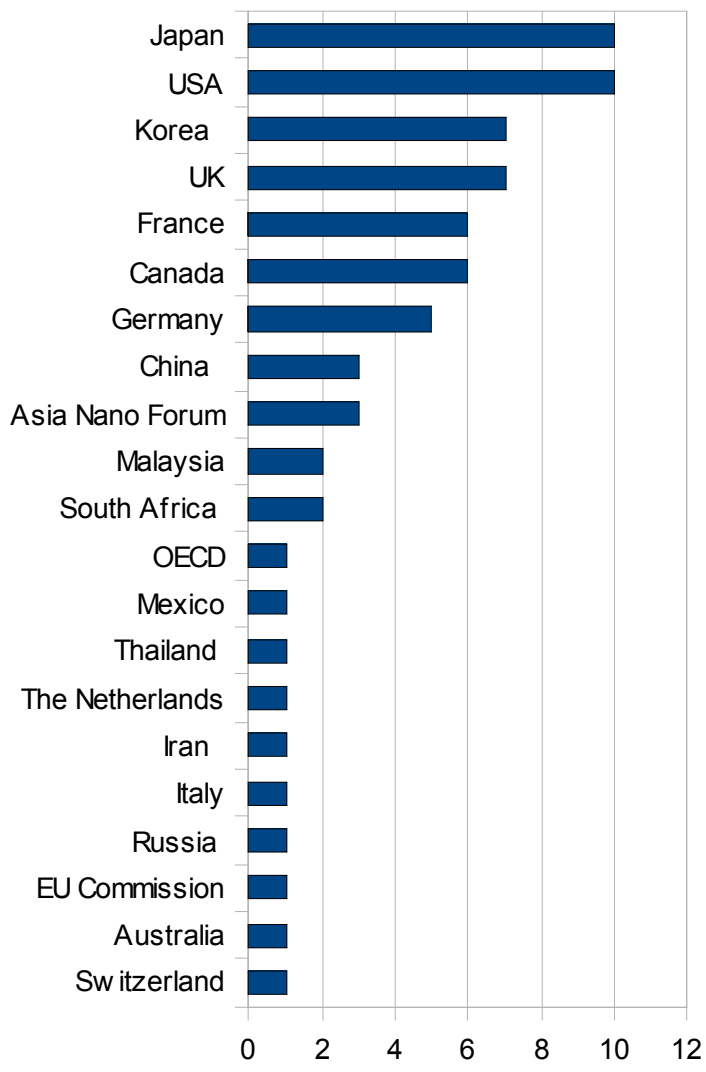

Over the three meetings considered here 348 participants registered in total, representing 31 different countries. 72 of them attended all three meetings and are considered the core of delegates.

Table 2: Institutional origins of participants (presence at all 3 meetings)

\begin{tabular}{|l|r|r|}
\hline \multicolumn{1}{|c|}{ Attendees } & number & \multicolumn{1}{c|}{$\%$} \\
\hline gouvernmental labs/org & 44 & $61 \%$ \\
\hline firms & 24 & $33 \%$ \\
\hline universities & 3 & $4 \%$ \\
\hline thers & 1 & $1 \%$ \\
\hline & 72 & 100 \\
\hline
\end{tabular}

\section{The liaisons with other TCs and organisations}

In addition to the national delegates, TC229, like any other ISO technical committee, includes representatives from various bodies, called liaisons. The establishment of liaisons in the standardisation system, is a way of formalising a contact between activities that are believed to have mutual benefits. This is both seen as a way for efficient communication, which in turn prevents double work and as a way to promote sensible demarcations between areas. Currently, TC 229 has established 27 liaisons. 18 of these are internal liaisons with other technical committees in the ISO system and more are expected (Figure 2 - the inner circle represents existing liaisons while the outer circle represents potential ones). There is 1 liaison with a technical committee in the International Electrotechnical Committee (IEC), and 8 liaisons with (external) organisations (Table 3) 


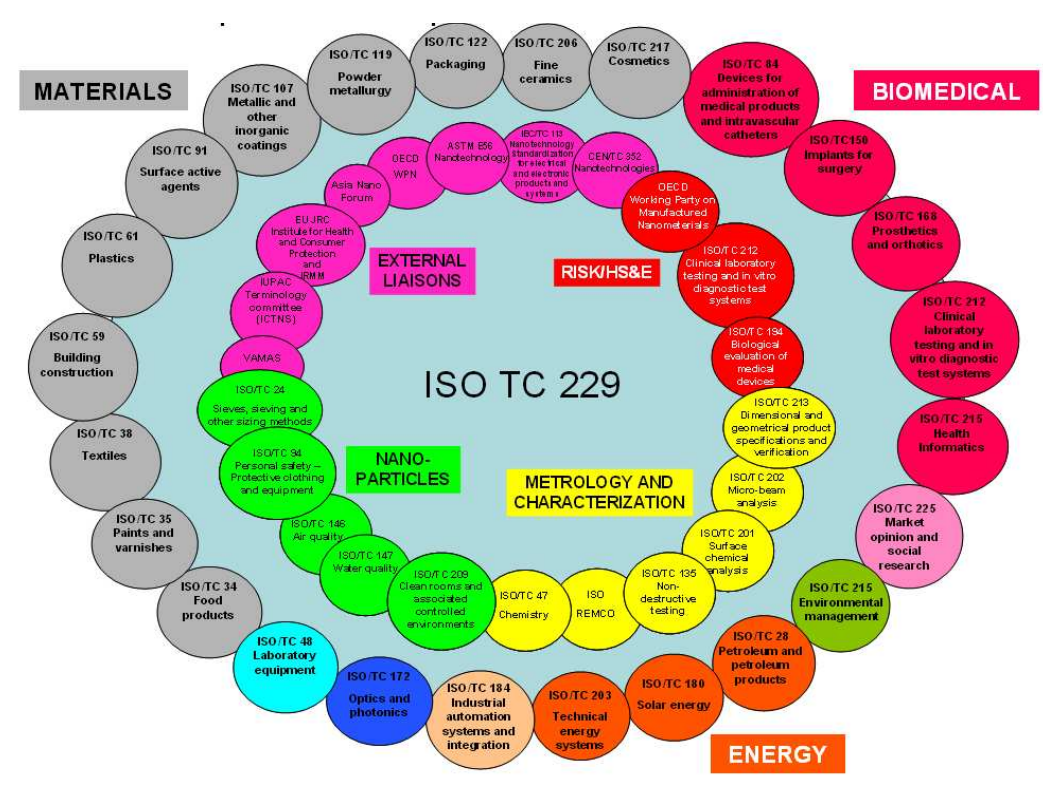

Figure 2 - TC 229's existing and Potential liaisons

Source: Hatto, 2008

Table 3: List of external organisations that have established a liaison with ISO/TC229 (: ISO, 2010b).

\begin{tabular}{|l|l|l|l|}
\hline Acronym & Full name & $\begin{array}{l}\text { Liaison } \\
\text { established }\end{array}$ & $\begin{array}{l}\text { No. of liaisons } \\
\text { with other ISO } \\
\text { groups }\end{array}$ \\
\hline JRC & $\begin{array}{l}\text { European Commission - Joint } \\
\text { Research Centre }\end{array}$ & 0 \\
\hline VAMAS & $\begin{array}{l}\text { The Versailles Project on } \\
\text { Advanced Materials and } \\
\text { Standards }\end{array}$ & 2006 & 12 \\
\hline ANF & Asia Nano Forum & 2007 & 0 \\
\hline BIMP & $\begin{array}{l}\text { International Bureau of Weights } \\
\text { and Measures }\end{array}$ & 2008 & 6 \\
\hline ECOS & $\begin{array}{l}\text { European Environmental Citizens } \\
\text { Organisation for Standardisation }\end{array}$ & $\begin{array}{l}\text { International Union of Pure and } \\
\text { Applied Chemistry }\end{array}$ & 2009 \\
\hline IUPAC & $\begin{array}{l}\text { Institute for Reference Materials } \\
\text { and Measurements } \\
\text { of the Joint Research Centre } \\
\text { JRC) }\end{array}$ & $\begin{array}{l}\text { Organisation for Economic Co- } \\
\text { operation and Development, } \\
\text { OECD }\end{array}$ & 25 \\
\hline OECD &
\end{tabular}




\section{Definition of activities of TC 229}

In a nutshell, the TC defines its mission as « to develop science-based standards for the field of nanotechnology in order to promote its commercial applications in a secure manner» (general assembly- June, 12th 2009)

To achieve this purpose, the TC is organised in four working groups (WG), four transversal task groups (TG) and various groups of coordination such as the chairman advisory committee (CAG). Initially, TC 229 was composed of only three WGs and the coordination groups (Figure 4). The fourth working group (WG4) was added in 2008 as well as the two task groups on "nanotechnology and sustainability" and "societal dimensions of nanotechnology". Note that the TC does not possess any sub-committees which usually is the norm for TCs within the ISO structure. Sub-committees are supposed to report to ISO and not directly to their own committee. This decision was made at the creation of TC229 to achieve a better coordination within the TC. It is reinforced by the transversal coordination task group as its Business Plan mentions: "Establishing a Task Group to consider the preparation and harmonization of road maps for Working Groups within TC229"

Figure $4-$ structure and working areas of TC 229

\section{TC 229 - Structure/working areas}

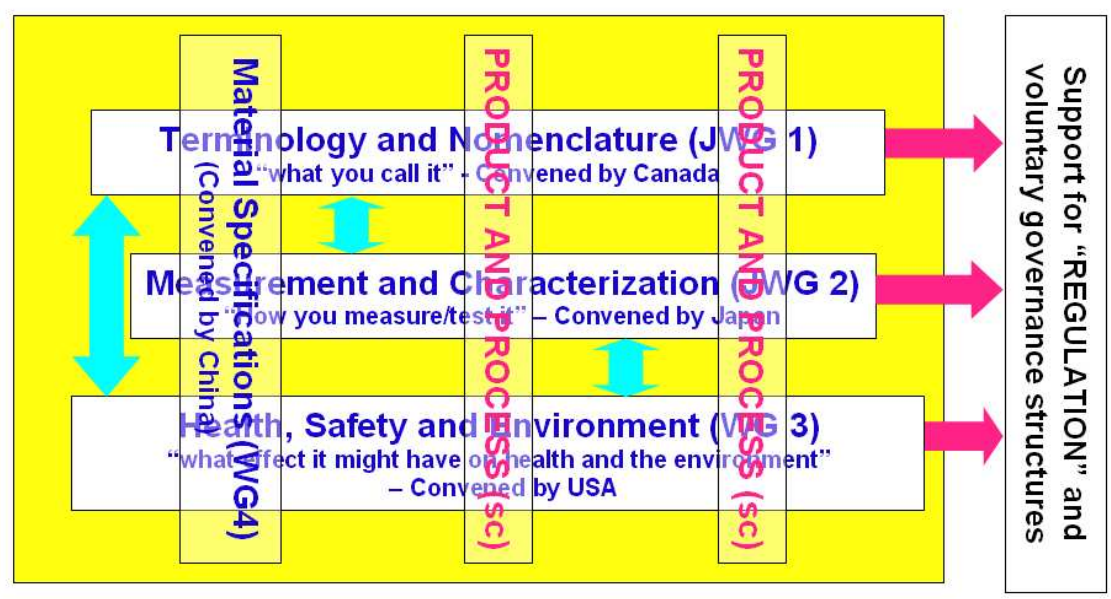

Source: Hatto, 2008

The objectives of the four working groups are:

- JWG 1 "terminology and nomenclature" convened by Canada. Since 2009, it is a joint working group with the IEC TC 113 which means that experts from the two organisations work together on the same documents. WG1 aims at creating "a common language for scientific, technical, commercial and regulatory processes"(TC 229 Business Plan, 2007). Its mission is «to establish a taxonomic terminology 
framework for describing and defining nanotechnologies in a clear and unambiguous manner; and thence to explore possible models for a nomenclature framework that could be the basis for appropriate regulatory systems » (Clive Willis, presentation to the general assembly, Nov $\left.21^{\text {st }}, 2008\right)$. This work is fundamental for the other working groups as without any agreed definition, norms and standards can not be enforced. JWG 1 brings together a group of academics from universities, experts from national standard bodies and from national laboratories, and from industrialists. This diversity leads to difficulties. Indeed, definitions and categorizations of terms should be based on an academic basis but the scientific definition of a term X may not be the same as the definition of the same term $\mathrm{X}$ used by industrialists leading to hard debates. JWG1 has proposed several technical specifications (TS) notably for core terms such as nanotechnology, nanoscience and nanomaterials. Canada took on this convenorship both out of national interest, but also because there was a need to have a fair representation of continents.

- JWG 2 "measurement and characterisation" convened by Japan. JGW 2 is also a joint working group with the IEC 113. It aims at developing standards in measurement "internationally accepted for quantitative scientific, commercial and regulatory activities" (TC 229 Business Plan, 2007). JWG 2 prepares technical specifications. Each of these is based on a measurement or an instrument used in the field of nanosciences and nanotechnologies. Until the Tel Aviv meeting (November 2009), methods were almost exclusively focusing on the characterization of single and multi wall carbon nanotubes, most probably due to the interest of Japanese in the field. The need to work on other nanomaterials and characterization methods was highlighted at the Tel Aviv general assembly to feed the other WGs'own work. This is now taken into consideration in JWG 2's roadmap.

- WG 3 "health, safety and environmental issues" convened by United Kingdom. The objective is to ensure "occupational safety, and consumer and environmental protection, promoting good practice in the production, use and disposal of nanomaterials, nanotechnology products and nanotechnology-enabled systems and products" (TC 229 Business Plan, 2007). UK took the lead of this WG due to the significant number and relative size of institutes working on theses issues in UK;

- WG 4 "Material specifications" convened by China. Created in 2008, it aims at establishing nanomaterials specifications for professionals. The group first met at the Bordeaux meeting in May 2008. Nanomaterial manufacturers from South Korea, Taiwan and Japan consitute the core of this WG. Calcium carbonate $\left(\mathrm{CaCO}_{3}\right)$ and titanium dioxide $\left(\mathrm{TiO}_{2}\right)$ are the first materials that have been taken into consideration as they are for the most part produced in Asia, but also because they have many industrial applications. The main difficulty of the group is to consider "what is specific about these materials and that should in a technical specifications" and to offer feasible and replicable tests in a day to day basis for industries.

In addition to these technical working groups, two task groups were created in 2008 (in addition to the planning and coordination task groups).

- TG "Nanotechnology and sustainability" led by a US company. Created at the request of the chairman of TC 229 following the Bordeaux meeting (May 2008), this task group is transversal to the whole committee. It met the first time at the Shanghai 
meeting (November 2008). A task group cannot propose new work items.It intends to fulfil a specific goal, sets in its letter of creation. This group is expected to look for areas in which norms could be developed to speed up the process for innovations linked to sustainability and that are close to the market. It is actually aiming at setting priorities for new work items: these items being directly linked to sustainability. An exemplary case could be water purification ${ }^{6}$. Underlying this is the need to show the positive impacts of nanotechnologies.

- TG "Consumer and Societal dimensions of nanotechnology" led the chairman of the US NNI coordination office. Its creation was announced at the Shanghai meeting (November 2008) at the request of the committee chairman. It first met at the Seattle meeting (June 2009). Its purpose is to take into consideration all nontechnical aspects of nanotechnology including ethical issues such as the participation of countries from the South hemisphere, of underrepresented groups and of the consumers. It is currently thinking about including "ethical" criteria to the evaluation of new working proposals.

And finally there are the Chairman's Advisory Committee and the planning and coordination task groups ${ }^{7}$.

- CAG - The Committee Advisory Group is the assembly of all working groups' leaders and of a set of 3 head of delegations elected for three years and coming from various part of the world. It assists the chairman in the definition and implementation of the activities of the committee.

- The coordination TG is a transversal task group that insures the coordination between all activities organised within TC 229.

- The planning TG is dealing with the planning of activities to be undertaken within the technical committee.

\section{Discussion : ISO TC 229 meetings as a FCE shaping and diffusing a collective vision of the emerging field}

We have discussed the role of standardisation in existing industries and we here discussed the role of standards in an emerging field, that cannot yet benefit from traditional product standards as such. We have presented the role of FCE in emerging fields (Anand and Jones, 2008; Scott et al., 2000) in general and have considered ISO TC 229 meetings specifically. Standardisation has already been the locus of such a study (Garud, 2008), but not in an emerging field. We do however argue for the value of this framework to highlight processes that impact on the dynamics of nanotechnologies. We show how the organisation and the reorganisation of the committee can shape the creation of a vision (Oliver and Montgomery, 2008) for the committee members at the first place, of the experts of the committee, of the

\footnotetext{
${ }^{6}$ Water purification was especially highlighted in the dinner speak pf the convenor of TC229 at a Banquette in Tokyo in June 2006. This is one of the few publicly available documents of TC229 at the ISO pages. (Hatto 2006)

${ }^{7}$ Note that other minor structures exist within TC 229 but that for the sake of clarity, we do not present them here.
} 
liaison officers up to outsiders of the field and the institutional level (Aldrich and Fiol 1994). Based on its organisation, the Chairman's Advisory Group (CAG) has presented an evolving picture of nanotechnologies : from a technical field that needed to be defined to a field that is taking into consideration the societal dimensions linked to science and innovation.

1. 2005 - end of 2007: London to Singapore meetings. Individual actors fighting for their interests and trying to impose their perspective of the evolution of nanotechnologies.

Created in 2005, its structure without sub committees and with planning and coordination task groups points to the need for transversality: the field of nanotechnology is emerging and yet not well structured. Standards and norms are not yet relevant as the field is still very science oriented and promises have not yet been translated into innovations (Larédo et al. 2009). The chairman of the committee thus insists on the value of «pre normative» work with technical reports (TR) and specifications (TS) if norms cannot be produced yet. Considering the number of projects 8 are TR, 22 are TS and 3 are norm projects. Out of the published documents 1 is a TR and 1 is a TS while there is not yet any norm documents.

This is also visible in the selection process of new work items. Subjects are widespread in scope and proposed by actors that have a direct interest in them Actors have their own view of the dynamics of the field and try to impose it by having their projects accepted, and other nations working on it. To take an example, due to the relative strenght of its domestic industry in electronics (which uses carbon nanotubes in batteries for example), Japan initiated a work on the characterisation of carbon nanotubes in WG2. For Japan, carbon nanotubes are strong elements in the nanotechnologies and should be at the core of the work. This behaviour was eased by the fact that many delegations do not have a clear vision of what they can do. Thus, they vote «yes» to projects even though they do not have any experts to contribute to the work or have any real interest in the subject. This is recognised as a challenge for the work of TC229: during ballots some countries might vote "Yes", even though an "Abstain" vote would be a more correct reflection of their position.

Delegations may not want to jeopardize the existence of TC 229 and do not want to vote against other nations' projects as to have them «return the favour» whenever they would propose a project. There was no selection process as a delegate interviewed at the Seattle meeting recognizes : «at the beginning of the committee, there was definitively a fear of the white page so to say. There was a need to start working on something.» This led to a multiplicity of projects, lacking a common approach and strategy. Accordingly, we would expect TC 229 to set stricter rules for the establishment of further standardisation projects in the coming future.

Accordingly We see actors trying to make sense out of the field (Oliver and Montgomery, 2008). There is no common idea or vision of the future developments of the field. Larédo et al. (2010) show the same trend when studying policies supporting the development of nanotechnologies. They point to the policies set up in most countries that are all inherited from the previous technological waves and that do not take into consideration the specificities of the dynamics of nanosciences and technologies.

2. end of 2007 - 2008 : Bordeaux meeting as a turning point. Introducing markets into nanosciences and technologies 
The meeting in Bordeaux in May 2008 was a turning point. As we have discussed above, TC 229 and its members are still exploring the field and creating as much as they can interest to mobilise forces. However, in 2007, TC 229 CAG started making sense out of the field and produced a first new version of its business plan since 2005. At the same time, WG groups started developing their own roadmaps that are discussed at the TC level both in the coordination TG and the CAG and at general assembly meetings. At the end of 2007, the first roadmap for TC229 as whole is produced. This need to organise activities and put order is not only happening at the strategic level of TC 229 but also at the national levels. We recall here the French initiative accounted for by a French delegate: he admits during an interview that the French delegation worked internally on a roadmap for WG3 so as to organise the work.

The shaping of a collective vision of the dynamics continues as a new WG is created during Bordeaux meeting in June 2008. As the Chinese had developed their own standards for materials specifications, they wanted to have them recognized at the international level. This can be seen as a remaining of the first period in which individuals actors (here a country) were trying to impose their interests upon other ones. But proposing the creation of a new working group is completely different than proposing a new work item. The creation of WG4 results from a collective thinking at the level of TC 229: for some nanomaterials, markets exist in a short term perspective. Markets need to be organised and that material specifications are thus required. This re organisation of TC 229 into $4 \mathrm{WG}$ acted as a signal for outsiders that nanoproducts were soon to arrive on the markets.

Bordeaux meeting is a turning point also because a new activity " task group nanotechnologies and sustainability" was announced by the chairman of TC229. It met for the first time in Shanghai in November 2008. While the committee recognized that markets for nanoproducts were organising, it also acknowledged the need to show the positive aspects of nanotechnologies. Indeed, throughout 2008, nanotechnologies were highly visible in newspapers and numerous citizen and consumers associations started to alert the society about dangers of nanotechnologies. The TC 229 thus felt a responsibility to promote the benefits of these technologies and proposed to foster projects of norms that would help "useful to the society" technologies to reach markets faster. The committee was pushed by its chairman to have this TG set up. He played the role of institutional entrepreneur (Delemarle, 2007; Greenwood and Suddaby, 2006) who envisions new institutions as a means of advancing interests they value and creates a cohalition to support him/her. Enrolling the CAG (composed of working group leaders and elected representatives of the participating countries) to support the creation of the TG and having the whole committee agreeing to it can be considered as such. The TG objective is to propose new work items that are linked to sustainable development. Again, the new aspect of TC 229 helped shaping the vision of nanotechnologies introducing to both the experts and the society to positive consequences of nanotechnologies. The TG and its results should come as a demonstration of the value of nanotechnologies (Lampel, 2001; Rao, 1994). This is the rationale for the creation of this new task group. Note also the fact that this TG is led by a company. It is not a minor point : companies are involved in TC 229 to influence the standardisation process so that their products will (more easily) fulfill the requirements set. Companies join the process also to learn more about markets, developments and competitors. Nanotechnology is thus not only a field of scientific explorations but also of commercial exploitations (Meyer et al., 2005)

\section{2008 : Shanghai meeting : introducing society into nanosciences and technologies}


In the continuity to the creation of the TG "nanotechnologies and sustainability", another task group was announced in Shanghai "consumer and societal aspects of nanotechnologies". The group first met in Seattle under the lead the chairman of the NNI coordination office. Again, the function of the leader of the group is not anecdoctical,: it signals the importance of these issues at the top of worldwide organisations. Consumers' representatives but also large companies participate to the discussions. They are all part of the institutional entrepreneur's support group to gain legitimacy; however, this time for a different purpose. It is not about the credibility of an emerging industry but the trust that can be placed into it (Aldrich and Fiol, 1994). While the TG "nano and sustainability" aims at showing the positive aspects of nanotechnologies, it does not re insure society. And as public debates around the world show, to put nano products on the market is more difficult than expected. The rationales of this TG are to create acceptability for nano products beyond the dimensions of health and safety that are discussed in WG3. As for now, discussions within this TG aim at increasing the participation to TC 229 by under represented groups and the society at large. It also proposes to include a selection criteria of new work item based on ethical issues, sending thus strong signals outside of TC 229 to the society at large and to build legitimacy for nanotechnologies ${ }^{8}$.

\section{Conclusions}

We have discussed the role of standardisation in the shaping of a collective vision in nanotechnology and most specifically how the organisation and re-organisation of TC 229 plays a crucial role in that.

We however started this paper on the willingness of regulation of nanotechnology and how this could be done. We showed that standardisation plays a role in regulation of markets but that it does so when products existed, which is not the case for nanotechnologies (at least not products using the benefits of the properties of matter at the nanoscale). Anticipatory standards in this situation are those that will be developed and work of TC 229 is defined as such (Hatto, 2008; ISO TC 229 Business Plan 2007). Note that together the terms "regulation" and "regulators" are used 12 times in the Business Plan of TC 229. This is probably both a will and a wish: the committee wants to signal that they expect to be/are important for future regulation, but even to attract the participation of both regulators and those wanting to influence such work.

However, the case that we discussed brings another aspect to the standardisation. By considering biannual meetings as field configuring events allows to point to its role of collective vision shaping. This vision will be used by regulators when defining rules. The legitimacy within the field and outside of it is currently built by members of these events. This legitimacy is also brought by the large diversity of actors in the consensus building with in TC 229. A common observation of standardisation regarding representation is that public interests tend to get marginalised (ANEC/BEUC 2009). Industry representatives tend dominate standardisation, and national regulatory experts and NGOs get marginalised through different mechanisms (e.g. lack of funding and resources).It is interesting to note that in the case we have presented here, the work in ISO TC229, it is the representatives from governmental laboratories and bodies that dominate, at least in numbers.

\footnotetext{
${ }^{8}$ Note that for the two TG described here, work is on-going and subject to change.
} 
As the work of TC229 is still on-going the extend to which it will succeed to have its vision shared is to be shown. However, the links that ISO TC229 creates with external international organisations and with other ISO TCs as well as the growing interest shown by the increasing attendance to the meetings (Maastricht meeting, May 2010) are strong supportive elements.

\section{REFERENCES}

Abbott, K.W., and Snidal, D. 2000. Hard and Soft Law in International Governance. International Organization, 54 (3), 421-456.

Aldrich, H.E and Fiol, C.M. 1994. Fools rush in? The institutional context of industry creation. Academy of Management Review, 19, 645-70

ANEC/BEUC 2009. Nanotechnology: Small is beautiful but it is safe? Joint ANEC/BEUC position. Available http://www.anec.org/attachments/ANEC-PT-2009-Nano-002final.pdf [Last Accessed 10 February 2010].

Brownsword, R. 2008. Rights, Regulation, and the Technological Revolution. Oxford: Oxford University Press.

Bryden, A. New ISO committee will develop standards for nanotechnologies. ISO Press release 978. Issued $10^{\text {th }}$ November 2005.

CEN 2006. BUSINESS PLAN CEN/TC 352 Nanotechnologies. Date: 2006-05-26

Version: Draft \#May06. Available

http://www.cen.eu/cen/Sectors/TechnicalCommitteesWorkshops/CENTechnicalCommitte es/Pages/PdfDisplay.aspx [Last Accessed February, 11th 2010]

Delemarle, A, 2007, Les leviers de l'action de l'entrepreneur institutionnel: le cas des micro et nanotechnologies et du pôle de Grenoble. PhD Thesis, Paris: Université Paris Est, Ecole des Ponts, Text available at http://pastel.paristech.org/2420/

Delemarle A., 2009a, Compte-rendu de la réunion du comité ISO TC 229 « Nanotechnology » Shanghai 17 au 21 novembre 2008. Report to the ADEIC

Delemarle A., 2009b, Standards and market construction in nanotechnology, presentation at the second international workshop on nanotechnology, society and policy, Manchester, October, 6th to $8^{\text {th }}, 2009$.

Delemarle, A., Kahane B., Villard L., Larédo P., 2009, Production in nanotechnologies: a flat world with many hills and mountains, Nanotechnology Law and Business, Spring 2009, 103-122.

EU 2009. European Parliament legislative resolution of 24 March 2009 (COM(2008)0049 - C6-0053/2008-2008/0035 (COD)

Garud, R. 2008. Conferences as venues for the configuration of emerging fields: the case of cochlear implants. Journal of Management Studies, 45, 1061-88 
Greenwood, R and Suddaby, R. 2006. Institutional entrepreneurship in mature fields: the Big Five accounting firms. Academy of Management Journal, 49, 27-48

Hatto, P. TC 229 Chairman's speech at Tokyo banquet, June 2006. ISO/TC 229 N 109. Document available at

http://isotc.iso.org/livelink/livelink? func=11\&objId=8927779\&objAction=browse \&sort=na me [Last accessed May 5th 2010].

Hatto, P. 2008. ISO/TC 229 - Nanotechnologies. Presentation at the ISO committee Chairs conference, Geneva, 5/6 June 2008. Document available at www.iso.org/iso/tc 229.ppt [Last accessed February, 10th 2010]

Hatto, P. 2009. Update on standardization for nanotechnologies. Presentation given at DEFRA Nanotechnology Stakeholder Forum, London, $7^{\text {th }}$ September 2009.

Hodge, G., Bowman, D., and Ludlow, K. 2007. Introduction: big questions for small technologies. In: G. Hodge, D. Bowman, and K. Ludlow, eds. New Global Frontiers in Regulation: The Age of Nanotechnology. Monash Studies in Global Movements. Cheltenham, UK: Edward Elgar, 2007, pp. 3-26.

ISO, 2008. General information on ISO [online]. International Organisation for Standardization. Available at www.iso.org/iso/support/faqs/faqs general_information_on_iso.htm [Last Accessed 15 February 2010].

ISO 2009. ISO in figures for the year 2008. ISBN 978-92-67-10495-9.

ISO 2010. ISO deliverables. Available at:

http://www.iso.org/iso/standards development/processes and procedures/deliverables.ht $\underline{\mathrm{m}}$ [Last Accessed 15 February 2010].

ISO/IEC 2007. Using and referencing ISO and IEC standards for technical regulations. 1600 - ISBN 978-92-67-10454-6. September 2007

ISO/IEC 2010. How are ISO standards developed?. International Organisation for Standardisation. Avialable at

http://www.iso.org/iso/standards_development/processes_and_procedures/how_are_stand ards_developed.htm [Last accessed 26 January 2010].

ISO/IEC 2010b. Standards Development/Technical Commitees/List of Technical Committees/TC 229. Avialable at

http://www.iso.org/iso/standards development/technical_committees/list of iso technica 1 committees/iso technical_committee.htm?commid=381983 [Last accessed 5 February 2010].

ISO/IEC 2010c. STANDARDS AND REGULATIONS. Information Centre: ISO/IEC. Available at

http://www.standardsinfo.net/info/livelink/fetch/2000/148478/6301438/standards_regulati ons.html [Last Accessed 15 February 2010] 
Keil, T. 2002. De-facto standardization through alliances - lessons from Bluetooth. Telecommunications Policy. 26 (2002), 205-213.

Lampel, J. 2001. Show and tell: product demonstrations and path creation of technological change. In: Garud , R and Karnoe, P. (eds), Path Creation as a process of mindful deviation. Mahawah, NJ. Lawrence Erlbaum, pp. 303-28

Lampel, J and Meyer, A.D. 2008. Field-Configuring Events as Structuring Mechanisms: How Conferences, Ceremonies, and Trade Shows Constitute New Technologies, Industries, and Markets. guest Editors Introduction. Journal of Management Studies, 45, 6, 1025-1035, September 2008

Larédo P., Kahane B. Delemarle A. and Villard L. 2009. Nanosciences et Nanotechnologies: A l'origine d'un nouveau cycle économique de longue durée? Présentation to the J3N, June 2009

Larédo P., Delemarle A.and Kahane B. 2010. Dynamics of nano sciences and technologies: policy implications. Working Paper LATTS-IFRIS. June 2010.

Ludlow, K., Bowman, D., and Hodge, G. , 2007. Conclusions: big regulatory questions something old, something new, something borrowed, something blue? In: G. Hodge, D. Bowman, and K. Ludlow, eds. New Global Frontiers in Regulation: The Age of Nanotechnology. Monash Studies in Global Movements. Cheltenham, UK: Edward Elgar, 2007, pp. 385-405.

Meyer, A.D, Gaba, V. and Colwell, K. 2005. Organizing far from equilibrium: non-linear change in organizational fields. Organization Science, 16, 456-73

Oliver, A.L and Montgomery, K. 2008. Using field-configuring events for sense-making: a cognitive network approach. Journal of Management Studies, 45, 1147-67

Ozin, G.A., and Arsenualt, A.C. 2005. Nanochemistry. A Chemical Approach to Nanomaterials. Cambridge, UK: RSC Publishing.

Rashba, E., Gamota, D., Jamison, D., Miller, J., and Hermann, K. 2004. Standards In Nanotechnology. Nanotechnology Law \& Business. 1.2 (2004), 185-192.

Rao, H. 1994. The social construction of reputation: contests, credentialing and legitimation in the American automobile industry: 1895-1912. Strategic Management, 15, $29-44$

Roco, M.C. and W. Bainbridge, Eds., 2001. Societal Implications of Nanoscience and Nanotechnology. Boston: Springer.

Spruyt, H. 2001. The supply and demand of governance in standard-setting: insights from the past. Journal of European Public Policy. 8 (3), 371-391.

Tassey, G. 2000. Standardization in technology-based markets. Research Policy. 29 (2000), 587-602. 
Throne-Holst, H., and Stø, E. 2008. Who should be precautionary? Governance of nanotechnology in the risk society. Technology Analysis \& Strategic Management. 20 (1), January 2008, 99-112.

Throne-Holst, H., Randles, S., Grieffenhagen, C., Strandbakken, P., and Stø, E. 2009. Risk, Responsibility, Rights, Regulation and Representation in the Value Chain of Nanoproducts. In: S. Arnaldi, A. Lorenzet and F. Russo, eds. Technoscience in Progress. Managing the Uncertainty of Nanotechnology. Amsterdam: IOS Press 2009, pp. 31-52.

Throne-Holst, H., and Strandbakken, P. 2009. Nobody Told Me I Was a Nano-Consumer. How Nanotechnologies Might Challenge the Notion of Consumer Rights. Journal of Consumer Policy. 32 (4), 393-402.

Wadman, M. 2009 Stem-cell inaction prompts concern. Nature News. Published online 24 February 2009. doi:10.1038/4571068a 